УДК 339.94

DOI: https://doi.org/10.37320/2415-3583/15.2

Ольшанський Г.О. головний спеціаліст

Управління із забезпечення державного оборонного замовлення та імпорту Державної компанії з експорту та імпорту продукції і послуг військового та спеціального призначення «Укрспецекспорт»

Корогодова O.O. кандидат економічних наук, доцент кафедри міжнародної економіки Національний технічний університет України «Київський політехнічний інститут імені Ігоря Сікорського» ORCID: https://orcid.org/0000-0003-2338-365X

\title{
УПРАВЛІНСЬКО-ОРГАНІЗАЦЙНІ ЗАСАДИ УКЛАДАННЯ МІЖНАРОДНИХ ДОГОВОРІВ У СФЕРІ ОПК УКРАЇНИ
}

У статті розглянуто передумови виникнення та розвитку міжнародних договірних відносин у сфері оборонно-промислового комплексу. На основі використання загальнонаукових методів дослідження сформовано уявлення про міжнародні економічні відносини у сфері ОПК як складну глобальну багаторівневу систему. Звернено увагу на особливості та відмінності міжнародної торгівлі в оборонній сфері. Зазначено, щяо в умовах глобалізаиї економічних відносин та посилення протекціоністських тенденцій окремих країн спостерігається значне зростання сукупних військових бюджетів світу. Проведено порівняння військових витрат у різних регіонах світу. Розглянуто процес формування та розвитку військово-технічної співпраці Украӥни з іншими крайнами. Надано характеристику оборонно-промислового комплексу України. Акцентовано увагу на чинниках, ще впливають на ефективність міжнародної торгівлі українських підприємств оборонно-промислового комплексу. Розглянуто та визначено чинники, ще впливають на обсяги експорту та імпорту товарів військового призначення. Виявлено важливість окремих чинників в економічному зростанні та збільшенні обороноздатності краӥни. Висвітлено специфіку міжнародних договорів в оборонній сфері. Визначено управлінські та організаційні особливості укладання міжнародних договорів для підприємств-спецекспортерів. Розглянуто прочес формування договорів у сфері ОПК Украӥни. Запропоновано класифікачію чинників впливу на процес укладання міжнародних договорів. Серед чинників макросередовища зазначено політико-правові, науково-технічні, економічні, природно-екологічні. Серед чинників мікросередовища запропоновано виділяти директивні органи, контактні організації, ринок товарів та послуг, конкурентів, інфраструктурні параметри. Авторами підсумовано головні особливості та відмінності міжнародної торгівлі в оборонній сфері України.

Ключові слова: військово-технічна співпраця, ТНК, управління у сфері оборонно-промислового комплексу, міжнародні договори у сфері ОПК, міжнародні економічні відносини.

Постановка проблеми. Виникнення міжнародних договірних відносин у сфері оборонно-промислового комплексу (ОПК) є результатом потреби країн у поліпшенні обороноздатності, бажання розвивати свою економіку за рахунок експорту наукоємних товарів із великою доданою вартістю та політичних цілей, спрямованих на покращення стратегічного партнерства 3 іншими державами. Важливими завданнями будь-якої прогресивної країни є забезпечення миру та безпеки у світі, на рівні окремих регіонів і країн, а також активна протидія поширенню міжнародної злочинності та тероризму. Реалізація цих завдань значною мірою залежить від ефективного і злагодженого функціонування національних систем експортного контролю державспецекспортерів. Основою міжнародних економічних відносин у сфері військово-технічної співпраці (ВТС) та партнерства між підприємствами оборонно-промислового комплексу є міжнародні договори. Важливість урахування особливостей організації укладання міжнародних договорів у сфері ОПК важко переоцінити. Викликає інтерес дослідження управлінських та організаційних засад формування та розвитку міжнародних економічних відносин у сфері ВТС.

Аналіз останніх досліджень і публікацій. Дослідження шляху розвитку оборонної промисловості та іiі впливу на національну безпеку привертає увагу бага- тьох науковців. Окремі аспекти аналізування структури військових бюджетів досліджувалися закордонними та вітчизняними фахівцями. Оцінювання воєнно-економічної безпеки, що пов'язана з експортним контролем, розглядається Н.М. Скляровою, Н.Г. Радовим [1]. Висвітлення процесів впливу розвитку підприємств оборонної галузі та стану їхньої фінансової безпеки на елементи системи національної безпеки відбувається у роботі П.О. Толок [2]. Оцінка глобальних військових витрат розглядається такими дослідниками, як Alexandra Kuimova, Diego Lopes da Silva, Pieter D. Wezeman та ін. [3; 4]. Однак, незважаючи на значну кількість праць із цієї проблематики, вона потребує подальшого дослідження, зокрема в частині вивчення особливостей укладання міжнародних договорів компаніями-спецекспортерами.

Мета статті полягає у визначенні управлінськоорганізаційних засад укладання міжнародних договорів у сфері ОПК України. Відповідно до вибраної мети, завданнями є: дослідження процесів міжнародної торгівлі товарами військового призначення (ТВП); порівняння військових витрат у різних регіонах світу; визначення управлінських та організаційних особливостей укладання міжнародних договорів для підприємств-спецекспортерів; класифікація чинників впливу на процеси формування договорів у сфері ОПК Укра- 
їни. Автори використовують загальнонаукові методи дослідження на базі системного та кількісно-якісного аналізу із застосуванням історично-логічного та синергетично-інформаційного підходів. Таким чином, міжнародні економічні відносини у сфері ОПК розглядаються як складна глобальна багаторівнева система. За допомогою табличного та графічного методів отримані дані узагальнено та систематизовано. Інформаційною базою проведеного дослідження $є$ дані міжнародних організацій та баз даних World Bank, SIPRI; інформаційно-аналітичні матеріали вітчизняних і зарубіжних науковців; нормативні документи, а також результати особистих напрацювань авторів.

Виклад основного матеріалу. Сучасна сфера міжнародної торгівлі товарами військового призначення значною мірою базується на державних бюджетах, адже основними замовниками ТВП є міністерства оборони та правоохоронні органи різних країн або державні установи, що виступають їхніми повноважними представниками на міжнародному ринку озброєнь та військової техніки. У звіті Стокгольмського інституту дослідження проблем миру (SIPRI) наводиться інформація щодо зростання майже у два рази сукупних військових бюджетів усіх країн світу за період із 1999 по 2019 р. Глобальні військові витрати, за оцінками дослідників SIPRI, становлять 1917 млрд дол. у 2019 р., що є найвищим показником із 1988 р. [3; 4]. Візуалізацію зазначеної інформації наведено на графіку (рис. 1).

Із зазначеного графіку також можна побачити, що приблизно половина військових витрат у будь-який момент часу припадає на Північну та Південну Америку. Європа та Азія витрачають приблизно однакові частки від загального обсягу витрат на оборону. Африку на графіку майже не видно, що свідчить про те, що більшість країн Африки тільки розвивається у напрямі самостійного забезпечення безпеки своїх країн. Оцінка статистичних даних по Європі (рис. 2) демонструє, що країни Східної Свропи активізували процеси мілітаризації та розвитку обороноздатності порівняно з поступовим зменшенням витрат на оборону в Західній Європі.

Зазначимо, що обсяги витрат державного бюджету України на оборону збільшилися зі 100\% до 150\% порівняно з 2010 р., що не дивно, зважаючи на те, що Україна з 2014 р. веде активні військові дії на сході країни. Своєю чергою, країни Західної Європи, навпаки, зменшили рівень військових витрат порівняно з 2010 р. Значною мірою виділяється своєрідний паркан серед країн Східної Свропи між Російською Федерацією та країнами Західної Європи. Приблизно 50\% оборонних бюджетів забезпечує утримання військовослужбовців, значна частка оборонного бюджету витрачається на забезпечення військових товарно-матеріальними цінностями, що виробляються всередині країни, і лише мала частина витрат передбачає закупівлю іноземного озброєння та військової техніки.

На міжнародному ринку ТВП основними гравцями виступають компанії - виробники зазначених товарів та уповноважені компанії-спецекспортери. За інформацією [3; 4], двадцять найбільших оборонно-промислових підприємств у світі отримали сукупний дохід у 220 млрд дол. США за 2018 р. У табл. 1 наведено дані щодо отриманого доходу десяти транснаціональних компаній та альянсів.

При цьому український державний концерн «Укроборонпром» у 2018 р. знаходився на 71-му місці із сукупним доходом у 1,3 млрд дол. США поряд із такими компаніями, як японська Fujitsu та польським оборонно-промисловим концерном PGZ. Слід зазначити, що порівняно з 2017 р. концерн поліпшив свою рейтингову оцінку на 12 позицій [4], однак ще

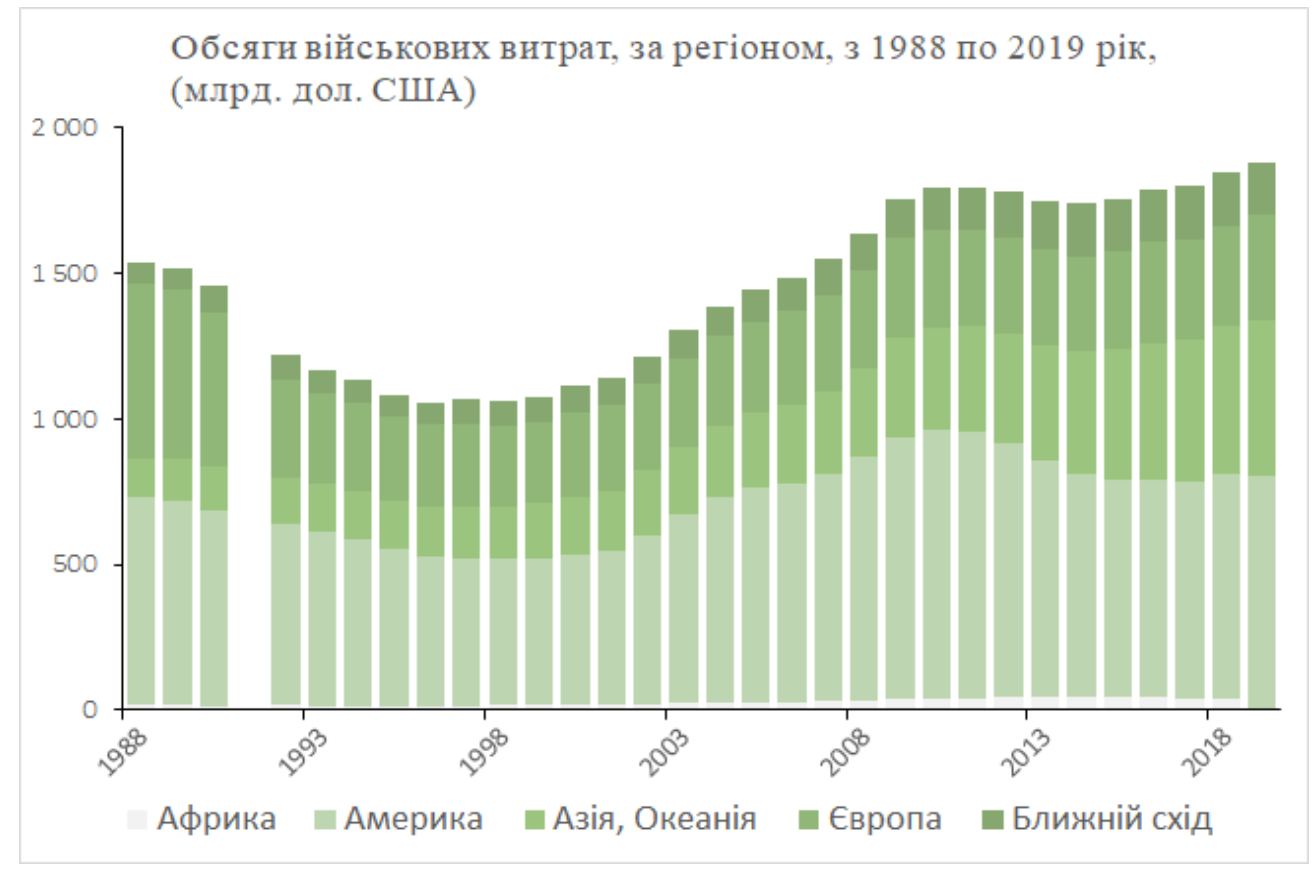

Рисунок 1 - Обсяги військових витрат за регіонами 
не перевищив рекордне значення 2013 р. (59-е місце). Під час порівняння показника доходу Державного концерну «Укроборонпром» із першою компанією в списку компанії постачальників ТВП отримано результат із різницею у приблизно 36 разів. Отже, українським підприємствам ОПК треба активізувати можливості ВТС із міжнародними організаціями та провідними компаніями задля забезпечення більших обсягів продажів. Зазначимо, що ВТС є каталізатором економічного та науково-технічного розвитку країни [1].

Організація укладання міжнародних договорів у сфері ОПК регламентується законодавством України та міжнародними угодами, що підписані урядом нашої країни у сфері ВТС. Процедура укладання та зміст самих договорів мають управлінсько-організаційні особливості через жорстку процедуру контролю над міжнародним переміщенням ТВП. Країни, що беруть участь у міжнародній торгівлі ТВП, відповідають за підтримання безпеки в регіоні та недопущення негативних наслідків торгівлі.

Ефективна міжнародна ВТС є передумовою укладання міжнародних (зовнішньоекономічних) договорів у сфері ОПК, що мають такі характерні особливості [5]:

- залежність від політичної стратегії ВТС з іншими країнами;

- дотримання положень міжнародного контролю над експортом та реекспортом ТВП, зокрема ліцензування;

- забезпечення офсетних угод у разі перевищення суми міжнародної передачі товарів (5 млн євро в українському законодавстві);

- можливість використання митних преференцій для звільнення від сплати від митних платежів під час імпорту ТВП за державним оборонним замовленням;

- посилений контроль державних органів над розрахунково-калькуляційним складником державних договорів на придбання ТВП;

- урахування міжнародних обмежень на торгівлю ТВП (ембарго та санкції);

- забезпечення умов посиленої конфіденційності, а також дотримання законодавства у сфері роботи 3 державною таємницею.

На додаток до вищезазначеного суб'єктам зовнішньоекономічної діяльності, які укладають зовнішньо-
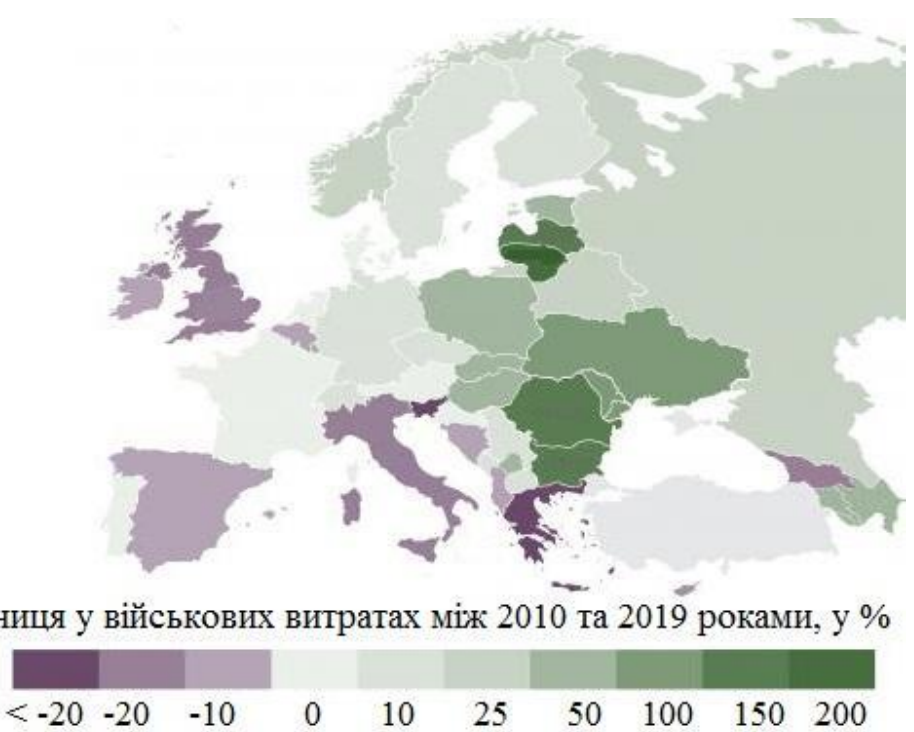

исунок 2 - Різниця у військових витратах країн Європи між 2010 та 2019 рр., \%

джерело: підготовлено на основі даних [3; 4]

економічні (міжнародні) договори (контракти) про експорт товарів, Кабінетом Міністрів України рекомендується вносити до них відомості про: мету і місце використання товарів; кінцевого користувача товарів; кінцеве призначення та кількість товарів; зобов'язання іноземного суб'єкта господарської діяльності щодо визначених вимог [6]. За рекомендацією Державної служби експортного контролю України до зовнішньоекономічного договору (контракту) можуть бути внесені додаткові положення, вимоги та зобов'язання [7]. Типову передконтрактну роботу державної компаніїспецекспортера з метою укладання міжнародних договорів на постачання або закупівлю ТВП під впливом дії чинників мікро- та макросередовища наведено на схемі (рис. 3).

Серед чинників мікросередовища компаній-спецекспортерів виділяємо ті, що безпосередньо впливають на виробничо-комерційну діяльність підприємства: ринок ТВП, споживачі, постачальники, конкуренти, а також контактні організації та директивні органи. До чинників макросередовища компаній-спецекспортерів у сфері ОПК відносимо природно-екологічні (використання потенціалу природних ресурсів, захист довкілля,

Таблиця 1 - ТОП-10 найбільших ТНК у сфері ОПК за рівнем отриманого доходу

\begin{tabular}{|c|l|c|c|c|}
\hline Місце & \multicolumn{1}{|c|}{ Компанія } & Країна базування & Продаж зброї, млрд дол. & $\begin{array}{c}\text { Загальний обсяг } \\
\text { продажів, млрд дол. }\end{array}$ \\
\hline 1 & Lockheed Martin Corp. & США & 47,3 & 53,8 \\
\hline 2 & Boeing & США & 29,2 & 101,1 \\
\hline 3 & Northrop Grumman Corp. & США & 26,2 & 30,1 \\
\hline 4 & Raytheon & США & 23,4 & 27,1 \\
\hline 5 & General Dynamics Corp. & США & 22,0 & 36,2 \\
\hline 6 & BAE Systems & В. Британія & 21,2 & 22,4 \\
\hline 7 & Airbus Group & Нідерланди & 11,7 & 75,2 \\
\hline 8 & Leonardo & Італія & 9,8 & 14,4 \\
\hline 9 & Almaz-Antey & Росія & 9,6 & 9,9 \\
\hline 10 & Thales & Франція & 9,5 & 18,8 \\
\hline
\end{tabular}

Джерело: побудовано авторами за [3; 4] 


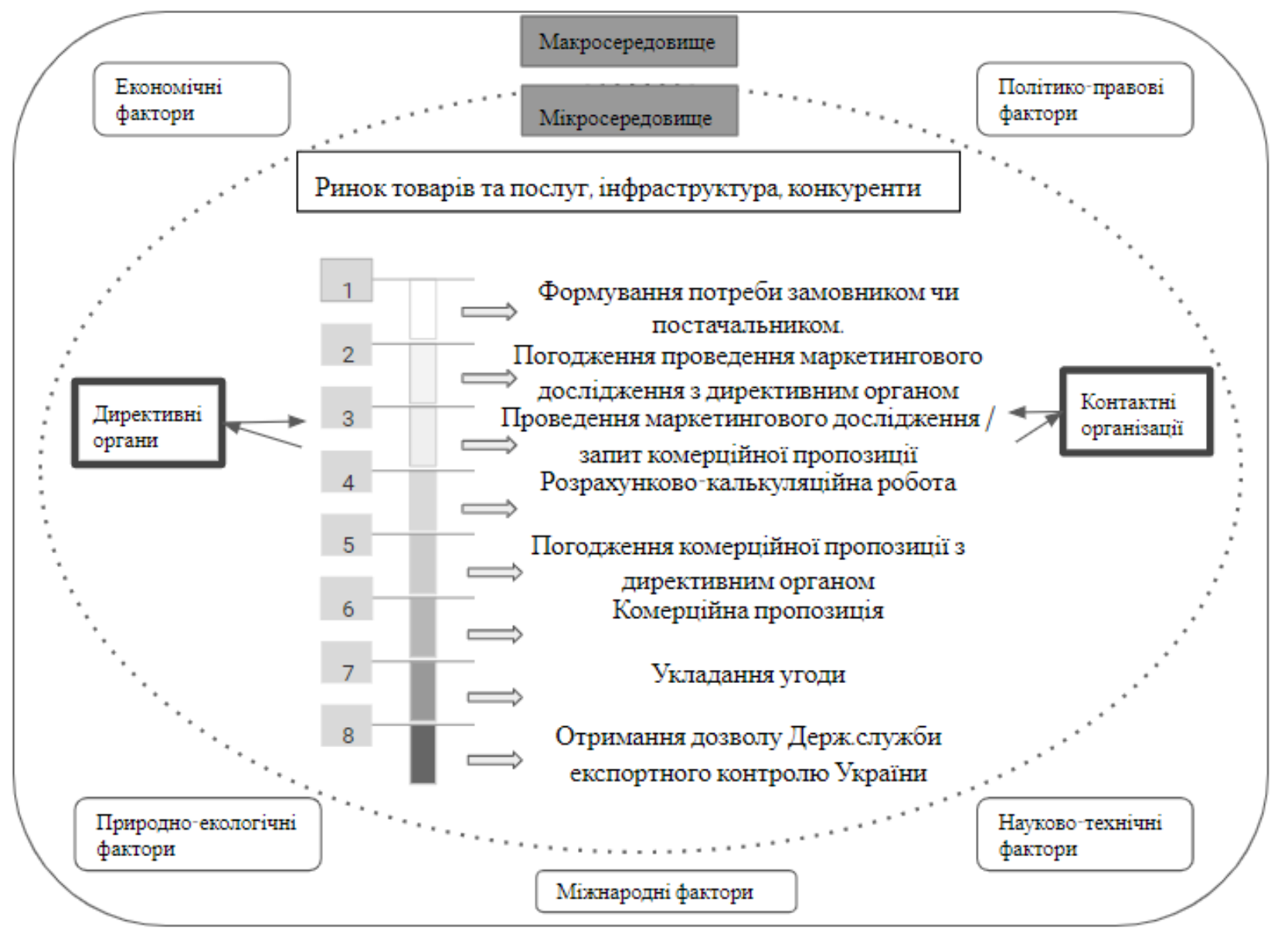

Рисунок 3 - Управлінсько-організаційні засади процесу укладання міжнародного договору державною компанією-спецекспортером у системі факторів мікро- та макросередовища ОПК

Джерело: побудовано авторами

вимоги щодо утилізації ТВП), науково-технічні (стан науково-технічного прогресу, кадровий потенціал ОПК, конкурентоспроможність та інноваційність ТВП), економічні (темпи росту ВВП, показники фінансово-кредитної системи, рівень розвитку податковомитних інституцій, стан реформ), політико-правові (відповідність інституційного забезпечення вимогам розвитку ОПК), міжнародні (виробнича та науковотехнічна кооперація, трансфер товарів та технологій, вплив міжнародних організацій та угруповань).

Одним із напрямів підвищення обсягів виробництва та реалізації ТВП уважаємо поліпшення законодавчої бази у сфері експортного контролю та пришвидшення проходження бюрократичних процесів, пов'язаних із передачею ТВП за кордон. Так, законодавчо закріплений термін отримання дозволу на експорт/імпорт ТВП від Державної служби експортного контролю України, що нині становить від 30 до 90 днів (з урахуванням часу на подання додаткової інформації за запитом контролюючих органів - термін фактично необмежений), можна було б зменшити до одного тижня та ввести систему електронного документообігу для полегшення роботи суб'єктів здійснення передач ТВП. Іншим управлінсько-організаційним завданням поліпшення стану ОПК України має стати імплемен- тація на оборонних підприємствах світових стандартів якості. Для зменшення рівня ризику також пропонується збільшити частку впливу страхових компаній як посередницьких структур у системі виробничо-комерційної діяльності підприємств ОПК. Зазначені вище пропозиції успішно використовуються передовими (здебільшого західними) країнами, що дає їм змогу займати провідні позиції на ринку озброєнь та військової техніки.

Висновки. Таким чином, досліджено, що в умовах одночасної глобалізації економічних відносин та посилення протекціоністських тенденцій окремих країн спостерігається значне зростання сукупних військових бюджетів світу протягом останніх 20 років. Результати регіонального аналізу свідчать, що, по-перше, майже $50 \%$ сукупних військових витрат припадає на країни Північної та Південної Америки; по-друге, відбувається активізація процесу мілітаризації економік країн Східної Європи. Зазначено важливу роль основних економічних агентів міжнародного ринку ТВП: виробників та спецекспортерів.

Указано, що управлінські та організаційні засади укладання міжнародних договорів у сфері обороннопромислового комплексу формуються під впливом низки інституційних, природно-екологічних, еконо- 
мічних, науково-технічних, міжнародних чинників, що зумовлюють передконтрактну роботу підприємств ОПК України. Урахування таких особливостей грає важливу роль в ефективності виконання договорів (контрактів), що, своєю чергою, значною мірою вПли- ває на імідж країни як надійного ділового партнера у сфері військово-технічної співпраці на міжнародній арені. Наведений напрям дослідження вважається авторами перспективним і буде докладно розглянутий у подальшому процесі наукового пошуку.

\section{Список використаних джерел:}

1. Скляр Н.М., Радов Д.Г. Методологія оцінювання воєнно-економічної безпеки, пов'язаної з експортним контролем. Стратегічні пріоритети. 2015. № 1(34). С. 34-40.

2. Толок П.О. Фінансова безпека підприємств оборонної галузі України у взаємодії із суб'єктами зовнішнього середовища : дис. ... канд. економ. наук : 21.04.02. Київ, 2019. 220 с.

3. Alexandra Kuimova, Diego Lopes da Silva, Pieter D. Wezeman, Siemon T. Wezeman. Trends in World military expenditure, 2019. URL: https://www.sipri.org/sites/default/files/2020-04/fs 2020_04 milex 0.pdf (дата звернення: 10.11.2020).

4. The SIPRI TOP 100 Arms-producing and military services companies, $20 \overline{1} 8$. Aude Fleurant, Alexandra Kuimova, Diego Lopes Da Silva, Nan Tian, Pieter D. Wezeman And Siemon T. Wezeman URL: https:/www.sipri.org/sites/default/files/2019-12/1912_fs_ top 100 2018.pdf (дата звернення: 10.11.2020).

5. Про затвердження Порядку здійснення державного контролю за міжнародними передачами товарів військового призначення : Постанова Кабінету Міністрів України від 20.11.2003 № 1807.

6. Зміни, що вносяться до Положення про порядок державного контролю за проведенням переговорів, пов'язаних 3 укладенням зовнішньоекономічних договорів (контрактів) про здійснення міжнародних передач товарів військового призначення та подвійного використання : Постанова Кабінету Міністрів України від 29.10.2003 № 1678.

7. Про затвердження Положення про Державну службу експортного контролю в Україні : Постанова Кабінету Міністрів України від 31.03.2015. Відомості Верховної Ради України. 2015. № 159.

\section{References:}

1.Skljar, N., Radov, D. (2015) "Metodologhija ocinjuvannja vojenno-ekonomichnoji bezpeky, pov'jazanoji z eksportnym kontrolem" [The methodology of estimation of military-economic security related to export control]. Strateghichni priorytety, vol. 1(34), pp. 34-40.

2. Tolok P. (2019) Finansova bezpeka pidpryjemstv oboronnoji ghaluzi Ukrajiny u vzajemodiji iz sub'jektamy zovnishnjogho seredovyshha [Financial security of defense industry enterprises of Ukraine in cooperation with external environment actors]. ( $\mathrm{PhD}$ Thesis), Kyiv.

3. Kuimova A., Lopes da Silva D., Wezeman P., Wezeman S. (2019) "Trends in World military expenditure". available at: https://www.sipri.org/sites/default/files/2020-04/fs_2020_04_milex_0.pdf (accessed 10 November 2020).

4. Fleurant A., Kuimova A., Lopes Da Silva D., Tian N., Wezeman P., Wezeman S. (2018) "The SIPRI TOP 100 Arms-producing and military services companies", available at: https://www.sipri.org/sites/default/files/2019-12/1912 fs top 100 2018.pdf (accessed 10 November 2020).

5. Postanova Kabinetu Ministriv Ukrajiny (2003) Pro zatverdzhennja Porjadku zdijsnennja derzhavnogho kontrolju za mizhnarodnymy peredachamy tovariv vijsjkovogho pryznachennja. 20 November 2003. No. 1807 / Kabinet Ministriv Ukrajiny.

6. Postanova Kabinetu Ministriv Ukrajiny (2003) Zminy, shho vnosjatjsja do Polozhennja pro porjadok derzhavnogho kontrolju za provedennjam pereghovoriv, pov'jazanykh z ukladennjam zovnishnjoekonomichnykh doghovoriv (kontraktiv) pro zdijsnennja mizhnarodnykh peredach tovariv vijsjkovogho pryznachennja ta podvijnogho vykorystannja. 29 October 2003. No. 1678 / Kabinet Ministriv Ukrajiny.

7. Postanova Kabinetu Ministriv Ukrajiny (2015) Pro zatverdzhennja Polozhennja pro Derzhavnu sluzhbu eksportnogho kontrolju v Ukrajini. 31.03.2015 / Vidomosti Verkhovnoji Rady Ukrajiny. No. 159. 
Olshanskyi Glib

State Defence Procurement and Import Department State Company for Export and Import of Military and Special Products and Services «Ukrspecexport»

Korohodova Olena

National Technical University of Ukraine «Igor Sikorsky Kyiv Polytechnic Institute»

\section{ORGANIZATIONAL AND MANAGERIAL PRINCIPLES FOR CONCLUSION OF INTERNATIONAL CONTRACTS IN THE SPHERE OF UKRAINIAN DEFENSE AND INDUSTRIAL COMPLEX}

The article considers the preconditions for the emergence and development of international contract relations in the sphere of defense and industrial complex. Based on the use of general scientific research methods, the international economic relations in the field of defense industry is described as a complex global multilevel system. The attention is paid to the features and differences of international trade in the defense sphere. It is noted that in the conditions of globalization of economic relations and strengthening of protectionist tendencies of some countries we observe the considerable growth of the aggregate military budgets of the world. The military spending in different regions of the world is compared herein. In the process of research we considered the formation and development of military-technical cooperation of Ukraine with other countries. The defense-industrial complex of Ukraine is characterized. Emphasis is placed on the factors influencing the efficiency of international trade of Ukrainian enterprises in the defense-industrial complex. Factors influencing the volume of exports and imports of military goods are considered and identified. The importance of certain factors for economic growth and increase of the country's defense capabilities is revealed. The specifics of international agreements in the field of defense are highlighted. The managerial and organizational features of concluding international contracts for special exporting enterprises are determined. The process of formation of agreements in the field of defense industry of Ukraine is considered. The classification of factors influencing the process of concluding international agreements is proposed. Among the factors of the macroenvironment are political and legal, scientific and technical, economic, natural and environmental factors. Among the factors of the microenvironment, it is proposed to highlight the government agencies, contact organizations, the markets of goods and services, competitors, infrastructure parameters. The authors summarize the main features and differences of international trade in the defense sphere of Ukraine.

Key words: military and technical cooperation, TNCs, management in the field of defense and industrial complex, international agreements in the field of defense industry, international economic relations.

JEL classification: F53, F52, F43, J53, M10 